\title{
Optimization and Physico-Chemical Characterization of a Bacteriocin Produced By Marine Lactobacillus Rhamnosus L43
}

\author{
Bharti Prakash Wadekar ${ }^{1}$, Smita M. Dharmadhikari ${ }^{2}$ \\ ${ }^{I}$ Research student Microbiology Department Government Institute of Science, Aurangabad \\ ${ }^{2}$ Associate Professor Microbiology Department Government Institute of Science, Aurangabad
}

\begin{abstract}
Objective: To optimize bacteriocin producing medium and their characterization.

Methods: Lactobacillus strain was isolated from marine water, Thirumullavaram beach, Kerala using MRS broth (Hi-Media, India) at $37^{\circ} \mathrm{C}$ for $48 \mathrm{hrs}$. The isolate was identified by $16 \mathrm{~S} r R N A$ sequencing and phylogenetic analysis. Optimization of physiological parameters and carbon, nitrogen sources. Produced crude bacteriocin and antagonistic characteristics of bacteriocin against Klebsiella pneumoniae MTCC535 were studied by agar well diffusion method. Bacteriocin stability in different temperature and enzyme.

Result: Lactobacillus rhamnosus strain isolated from marine water. Lactobacillus isolate was sequenced which shown high similarity with reference strain Lactobacillus rhamnosus ZY Accession number KC012630.1. Bacteriocin produced at $30^{\circ} \mathrm{C}, \mathrm{pH} 7,18 \mathrm{hrs}$. incubation time with $2 \%$ inoculum size and $2 \% \mathrm{NaCl}$ concentration. It produced in presence of lactose and peptone. All the data validated by statistical analysis using paired t-test by MINITAB 14. This bacteriocin was stable at $100^{\circ} \mathrm{C}$ for $20 \mathrm{~min}$, and it is in proteinaceous nature. Conclusion: These results indicated the potent strain produce bacteriocin. Maximum bacteriocin production was observed at $30^{\circ} \mathrm{C}, 18 \mathrm{hrs}$. incubation, $\mathrm{pH} 7.0,2 \% \mathrm{NaCl}$ solution.
\end{abstract}

Keywords: antibacterial activity, bacteriocin, Klebsiella pneumoniae, Lactobacillus sp.

\section{Introduction}

Bacteriocins differ from most therapeutic antibiotics in being proteinaceous agents that are rapidly digested by proteases in human digestive tract. A large no. of LAB bacteriocins have been identified and the list is still growing. They are ribosomally synthesized peptides and this facts creates the possibility of improving their characteristics to enhance their activity and spectra of action [1]. Bacteriocin from LAB are natural antimicrobial peptides or proteins with interesting potential applications in health care and food preservatives. Bacteriocins of Gram +ve bacteria are generally divided into four classes based on size, morphology, physical and chemical properties [2]. Class I bacteriocin are Lantibiotics, which are small peptides $(<5 \mathrm{kda})$ [3] Class II bacteriocin are small heat stable pepides $(<10 \mathrm{kda})$ that are not post transnationally modified class 111 are generally large $(>10 \mathrm{kda})$, heat labile peptides and class IV are covalently bonded which have cyclic structure.

Lactic acid Bacteria is a rich source of variety of antibacterial compounds like organic acid, diacetyl, $\mathrm{H}_{2} \mathrm{O}_{2}$, reuterin, bacteriocin or other bactericidal proteins which were produced during lactic acid fermentation [4]. Hence it is important to optimise the process parameters to enhance the production of either of compound. In present paper we have focused on optimisation of physiological parameters to enhance the bacteriocin production and further characterisation to monitor its antimicrobial potential against known human pathogen Klebsiella pneumoniae MTCC 535.

\subsection{Molecular identification of Lactobacillus sp.L43}

\section{Material And Methods:}

Lactobacillus sp.L43 strain with potent inhibitory activity was characterized to the species level using $16 \mathrm{~S}$ rRNA sequencing. The 16S rRNA gene of the isolate was sequenced (ABI 3100sequencer and genotyper; Genei) after the DNA isolation and PCR amplification. The sequence obtained was compared to the GenBank nucleotide database with BLAST [5] and phylogenetically analyzed using MEGA 5.03 software. (Xcelris Labs Ltd., Ahmedabad, India )

\subsection{Process Optimisation}

2.2.1 Optimization of Physiological parameters: De Man Rogosa Agar was used for bacteriocin production under various physiological conditions viz. $\mathrm{pH}(1,2,3,4,5,6,7,8,9,10)$, temperature $\left(20,25,30,37,40{ }^{\circ} \mathrm{C}\right)$, incubation period $(6,12,18,24,30,36,42,48$ hrs.), inoculum size $(0.5,1,1.5,2,2.5,3,3.5,4,4.5,5 \%), \mathrm{NaCl}$ concentration-(0.5, $1,1.5,2,2.5,3,3.5,4,4.5,5 \%)$.

2.2.2 Effect of various carbon and nitrogen sources: Various carbon and nitrogen source used for production of bacteriocin, carbon source viz. glucose, sucrose, maltose, ,mannitol, lactose, starch, cellulose, ribose, xylose, 
fructose and Nitrogen source viz. peptone, yeast extract, beef extract, meat extract, ammonium nitrate, ammonium chloride, casein, sodium nitrate.

2.3 Production of Crude bacteriocin: After termination of bacteriocin production the fermented liquor was separated from supernatant by centrifugation at $12,000 \mathrm{rpm}$ for 10 minutes at $4^{\circ} \mathrm{C}$. The cell free supernatant was neutralize to $\mathrm{pH} 7.0$ using $0.1 \mathrm{~N} \mathrm{NaOH}$ to inactivate the lactic acid released in fermented liquor.[6]. The crude prepared bacteriocin present in supernatant was filter sterilized by passage through a $\mathbf{0 . 2 2}$ um pore size membrane filter and used for further studies.

2.4 Bacteriocin assay: Bacteriocin assay has been carried out to determine antibacterial activity of all crude bacteriocin produced during process optimisation against sensitive culture of Klebsiella pneumoniae MTCC 535 by well diffusion method suggested by [7]. Aliquots (100ul) of various dilutions of crude bacteriocin prepared in sterile MRS broth $(2,4,6,8, \& 10$ fold) were placed in $7 \mathrm{~mm}$ diameter wells that had been cut in MH agar (Himedia lab. Pvt. Ltd. Mumbai, India) plates previously seeded with sensitive bacterium. After 24 hrs. of incubation at $37^{\circ} \mathrm{C}$, the diameter of the zone of inhibition was measured. Antibacterial activity was expressed in arbitrary units (AU/ml). 1 AU was defined as the reciprocal of the highest level of dilution resulting in a clear zone of inhibition

\subsection{Physico-Chemical Characterization of bacteriocin}

2.5.1 Effect of Enzymes: Effect of various enzymes viz. Proteinase K, trypsin, pepsin, lysozyme, alpha amylase, RNAse was determined in terms of its inhibitory effect towards antimicrobial activity of bacteriocin. The crude bacteriocin was treated with various enzymes at $1 \%$ level by incubating in presence of enzyme at $30^{\circ} \mathrm{C}$ for 2 hours. Then treated product was tested for its antibacterial activity. [8].

2.5.2 Heat Stability of bacteriocin: The crude bacteriocin was incubated at various temperatures viz.30, 50, 70, $90,100,121^{\circ} \mathrm{C}$ for 20 minutes. Then treated product was tested for its antibacterial activity. [9]

2.6 Statistics analysis

Each experiment was repeated twice and each determination was done in duplicate. The data were examined by analysis of Paired t-test using MINITAB 14 at a level of significance of $p<0.05$.

\section{Result And Discussion:}

3.1 Molecular identification of Lactobacillus sp.L43: The bacterial strain L43, isolated from Thirumullavaram beach, Kerala(water), this had the maximum inhibitory potential and was characterized by $16 \mathrm{~S}$ rRNA sequencing. The L43 strain revealed 99\% similarity with Lactobacillus rhamnosus strain ZY (Accession Number: KC012630.1) based on nucleotide homology and Phylogenetic analysis by Neighbour Joining method (Fig. 1) and hence designated as Lactobacilllus rhamnosus L43.

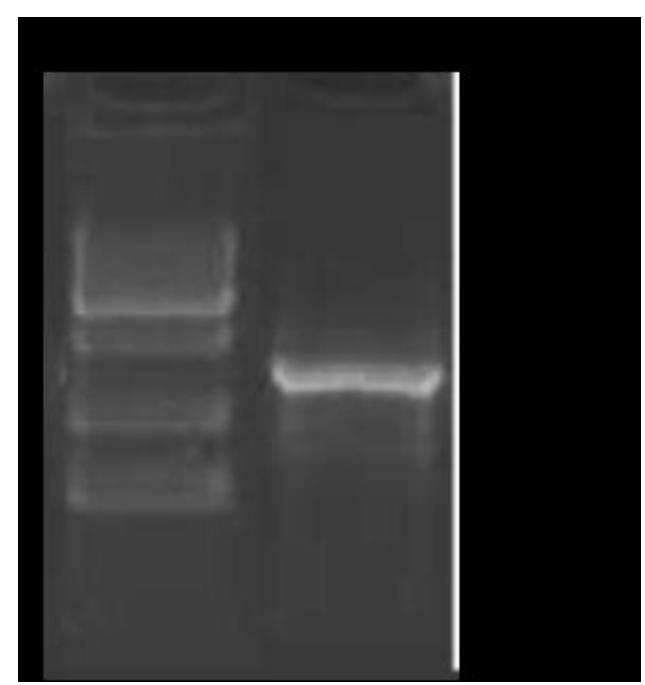

Figure 1: $0.8 \%$ Agarose gel showing single $1.5 \mathrm{~kb}$ of $16 \mathrm{~S} r D N A$ amplicon. Lane 1: $1 \mathrm{~Kb}$ DNA ladder; Lane 2: $16 S$ rDNA amplicon

ACGCCGCGTGAGTGAAGAAGGCTTTCGGGTCGTAAACTCTGTTGTTGGAGAAGAATGGTCGGCAG AGTAACTGTTGTCGGCGTGACGGTATCCAACCAGAAAGCCACGGCTAACTACGTGCCAGCAGCCG CGGTAATACGTAGGTGGCAAGCGTTATCCGGATTTATTGGGCGTAAAGCGAGCGCAGGCGGTTTTT TTAAGTCTGATGTGAAAGCCCTCGGCTTAACCGAGGAAGTGCATCGGAAACTGGGAAACTTGAGT ACAGAAGAGGACAGTGGAACTCCATGTGTAGCGGTGAAATGCGTAGATATATGGAAGAACACC 
Optimization and physic-chemical characterization of a bacteriocin produced by marine

AGTGGCGAAGGCGGCTGTCTGGTCTGTAACTGACGCTGAGGCTCGAAAGCATGGGTAGCGAACAG GATTAGATACCCTGGTAGTCCATGCCGTAAACGATGAATGCTAGGTGTTGGAGGGTTTCCGCCCTT CAGTGCCGCAGCTAACGCATTAAGCATTCCGCCTGGGGAGTACGACCGCAAGGTTGAAACTCAAA GGAATTGACGGGGGCCCGCACAAGCGGTGGAGCATGTGGTTTAATTCGAAGCAACGCGAAGAACC TTACCAGGTCTTGACATCTTTTGATCACCTGAGAGATCAGGTTTCCCCTTCGGGGGCAAAATG ACAGGTGGTGTATGGTTGTCGTCAGCTCGTGTCGTGAGATGTTGGGTTAAGTCCCGCAACGAGCGC AACCCTTATGACTAGTTGCCAGCATTTAGTTGGGCACTCTAGTAAGACTGCCGGTGACAAACCGGA GGAAGGTGGGGATGACGTCAAATCATCATGCCCCTTATGACCTGGGCTACACACGTGCTACAATG GATGGTACAACGAGTTGCGAGACCGCGAGGTCAAGCTAATCTCTAAGCCATTCTCAGTTCGGACTG TAGGCTGCAACTCGCCTACACGAAGTCGGAATCGCTAGTAATCGCGGATCAGCACGCCGGTGAAT ACGTTCCCGGGCCTTGTACACACCGCCCGTCACACCATGAGAGTTTGTAACACCCGAAGCCGGTGG CGTAACCCTTTTAGGGAGCGAGCCGTCTAAGGTGGGACAAATGATTAGGGTGAAGTCGTAACAAG G

Figure 3: Consensus Sequence (1112bp)

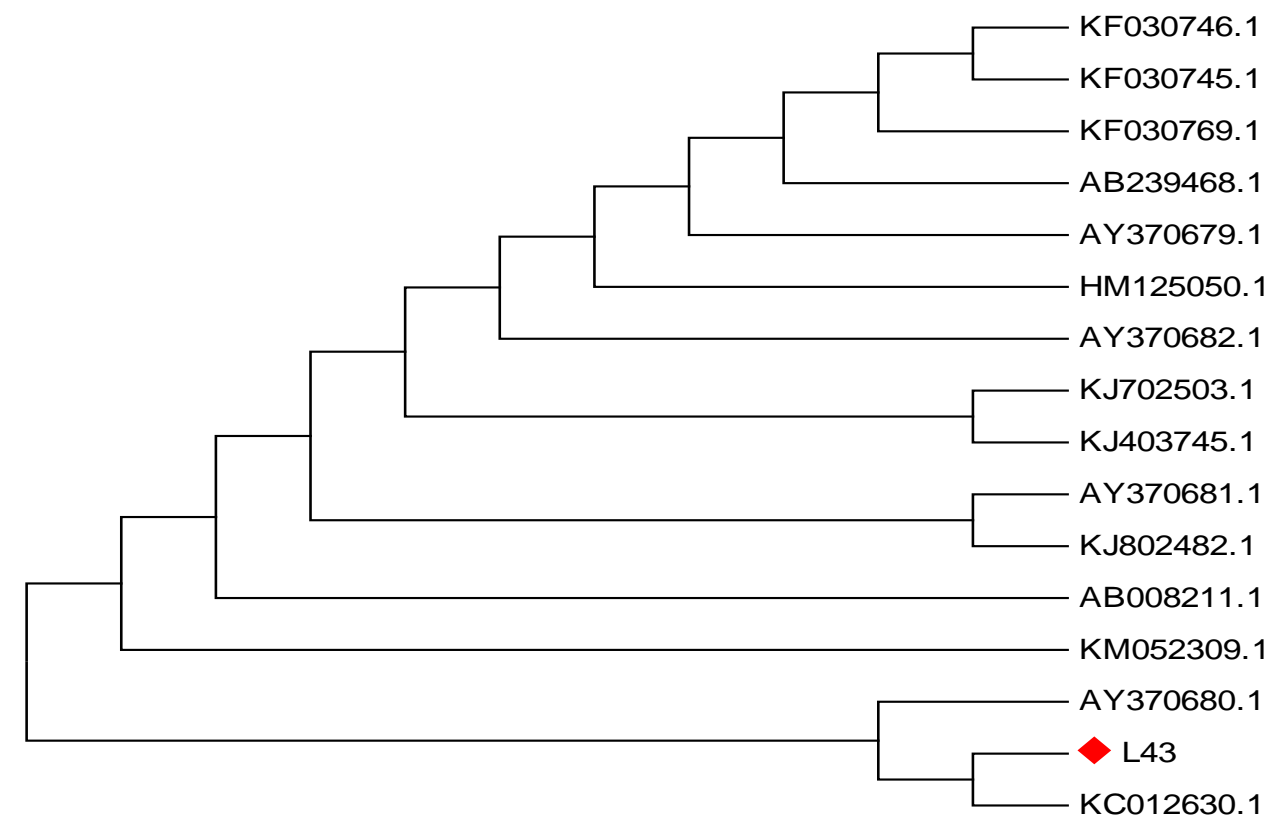

Figure 2: Phylogenetic tree

\subsection{Optimization of Physiological parameters}

3.2.1. Effect of temperature: The maximum arbitrary unit was measured as $1600 \mathrm{AU} / \mathrm{ml}$ at $30^{\circ} \mathrm{C}$ and minimum level as $880 \mathrm{AU} / \mathrm{ml}$ at $20^{\circ} \mathrm{C}$ (figure 4)

3.2.2. Effect of $\mathbf{p H}:$ Regarding $\mathrm{pH}$ the maximum arbitrary unit was measured as $1680 \mathrm{AU} / \mathrm{ml}$ at $\mathrm{pH} 7.0$ and minimum in $720 \mathrm{AU} / \mathrm{ml}$ at $\mathrm{pH} 1$ and 9. (figure 4)

3.2.3. Effect of incubation period: At various period of incubation maximum level as $1520 \mathrm{AU} / \mathrm{ml}$ at $18 \mathrm{hrs}$. and minimum level as $720 \mathrm{AU} / \mathrm{ml}$ at $54 \mathrm{hrs}$. (figure 5)

3.2.4. Effect of salt concentration: Various concentration of salt tested from 0.5 to $5 \% \mathrm{NaCl}$, The maximum production obtained as $1360 \mathrm{AU} / \mathrm{ml}$ at $2 \%$ and minimum in $720 \mathrm{AU} / \mathrm{ml}$ at $0.5 \%$.(figure 5)

3.2.5. Effect of inoculum size: The maximum production obtained as $1680 \mathrm{AU} / \mathrm{ml}$ at $2 \%$ inoculum and minimum in $800 \mathrm{AU} / \mathrm{ml}$ at $0.5 \%$. Results showed that L. acidophilus and L. Plantarum produced bacteriocin in MRS broth[11]. The strain L. plantarum exhibited a good bacteriocin activity of $2242 \mathrm{AU} / \mathrm{ml}$, at $\mathrm{pH}$ 6.0, sodium chloride $1.5 \%$ and $30{ }^{\circ} \mathrm{C}$. The strain L. acidophilus exhibited a good bacteriocin activity of $2432 \mathrm{AU} / \mathrm{ml}$, at $\mathrm{pH}$ 5.0 , sodium chloride $1.5 \%$ and $25{ }^{\circ} \mathrm{C}$. Bacteriocin production was strongly dependent on $\mathrm{pH}$, nutrient source and temperature. Various physicochemical factors seemed to affect bacteriocin production as well as its activity [11]. Maximum activities were noted at $\mathrm{pH} 5.0$ and $\mathrm{pH} 6.0$, temperatures $25^{\circ} \mathrm{C}$ and $30^{\circ} \mathrm{C}$ and $1.5 \% \mathrm{NaCl}$. It was well known that $\mathrm{NaCl}$ is required by many bacteria, for $\mathrm{Na}+$ is important to the osmotic pressure to the cells. But $\mathrm{NaCl}$ was not needed for other bacteriocin production [12]. In this study, $\mathrm{NaCl}$ played an important part to the growth of the bacteria. 
3.2.6. Effect of carbon and nitrogen source: The maximum activity was observed as $1600 \mathrm{AU} / \mathrm{ml}$ in presence of lactose and minimum activity was observed as $1000 \mathrm{AU} / \mathrm{ml}$ in presence of ribose. The maximum production was obtained as $1600 \mathrm{AU} / \mathrm{ml}$ in peptone and minimum level $720 \mathrm{AU} / \mathrm{ml}$ with ammonium chloride. (figure 5). The optimal growth conditions for bacteriocin production were found to be glucose-1.0\% as carbon source, $0.5 \%$ sodium nitrate as nitrogen source with $24 \mathrm{hrs}$ incubation [13].

\subsection{Characterization of bacteriocin:}

3.3.1 Effect of Enzymes: In presence of alpha amylase, RNAse, lipase were positive effect of bacteriocin production. Protease-k, trypsin and pepsin were strongly inhibited bacteriocin production. Bacteriocin production from L. fermentum KN02 was influenced when incubated in proteolytic enzyme (papain) [8]. Bacteriocin activity was completely affected by the enzyme papain, as it also was the case with nisin, the only established bacteriocin for commercial use until date. So the results show that the antibacterial compounds produced are inactive by the proteolytic enzyme (papain), indicating that the inhibitory compound are proteinaceous nature, a general characteristic of bacteriocin [14].

3.3.2 Heat Stability of bacteriocin: Heat stability observed at $100^{\circ} \mathrm{C}$ treatment for $20 \mathrm{~min}$. The bacteriocin GP1 produced by Lb. rhamnosus had a remarkable stability over heat treatment even at the autoclaving temperature for $20 \mathrm{~min}$ [9]. Heat stability of Lactobacillus. plantarum $\mathrm{F} 12$ at $100^{\circ} \mathrm{C}$ is important if the bacteriocin is used as a food preservative, because many procedures of food preparation involve a heating step.

3.4 Statistical analysis: Paired t-test for zone of inhibition with optimization had shown p-value $<0.05$.
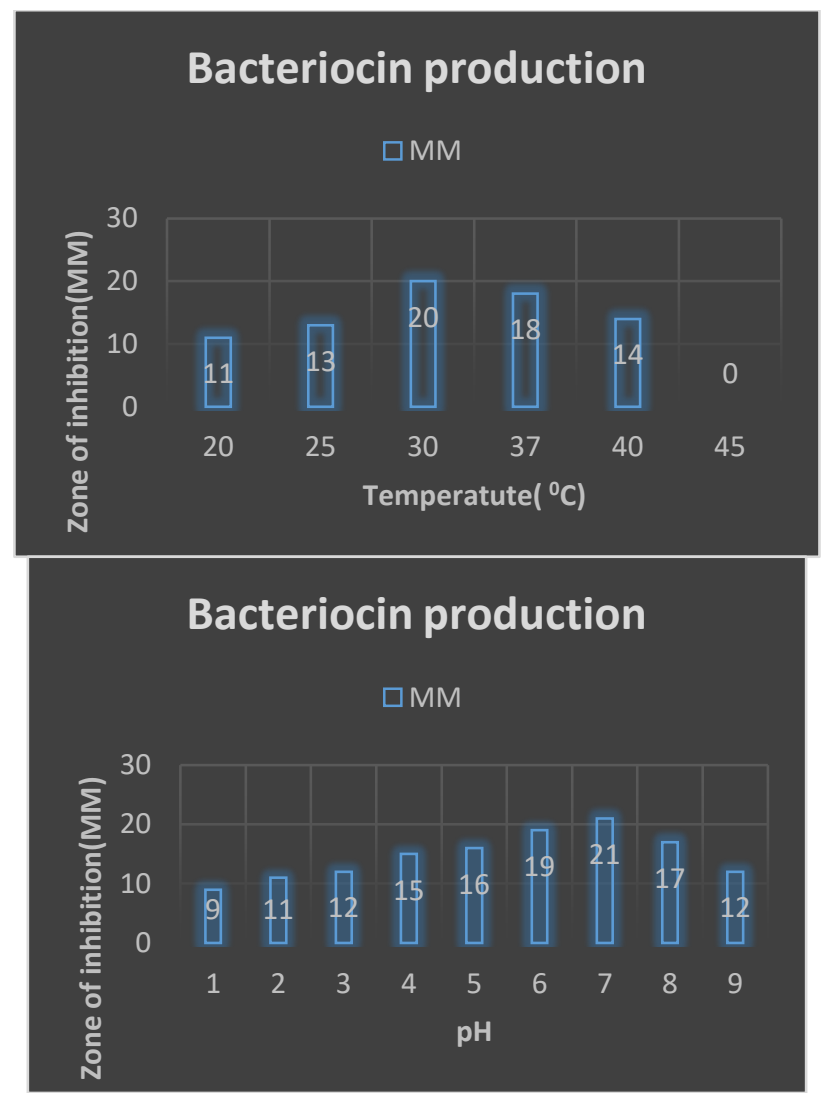

Figure 4: Effect of temperature and $\mathrm{pH}$ on bacteriocin production 

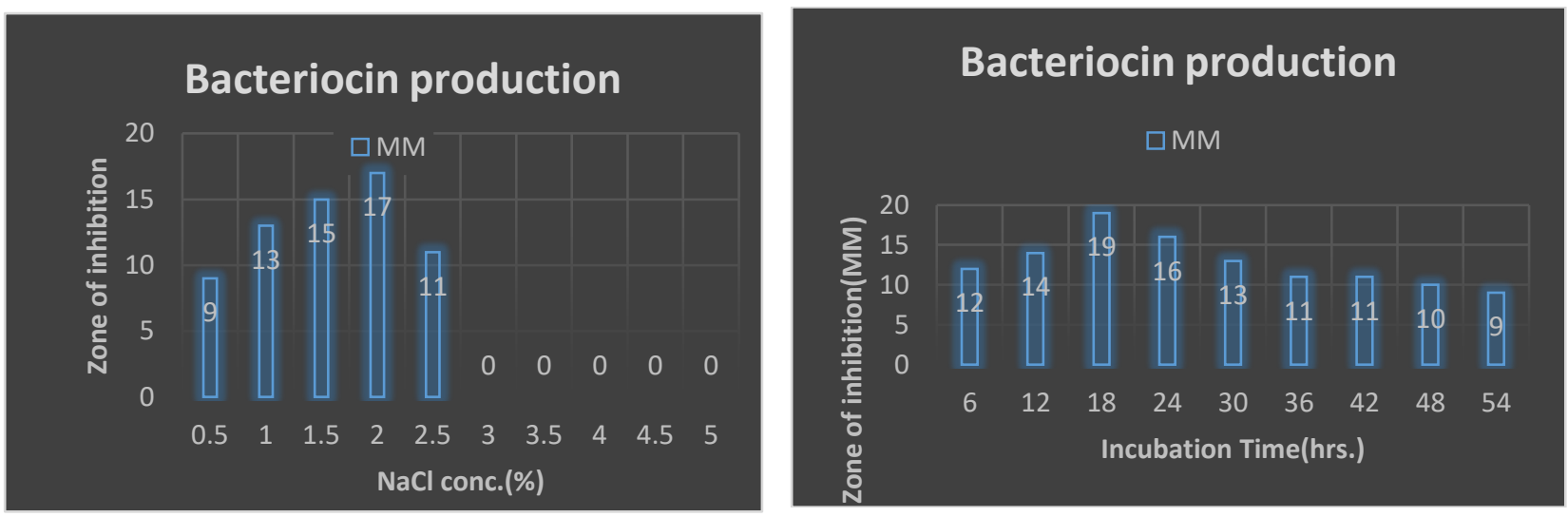

Figure 5: Effect of Incubation time and $\mathrm{NaCl}$ concentration on bacteriocin production
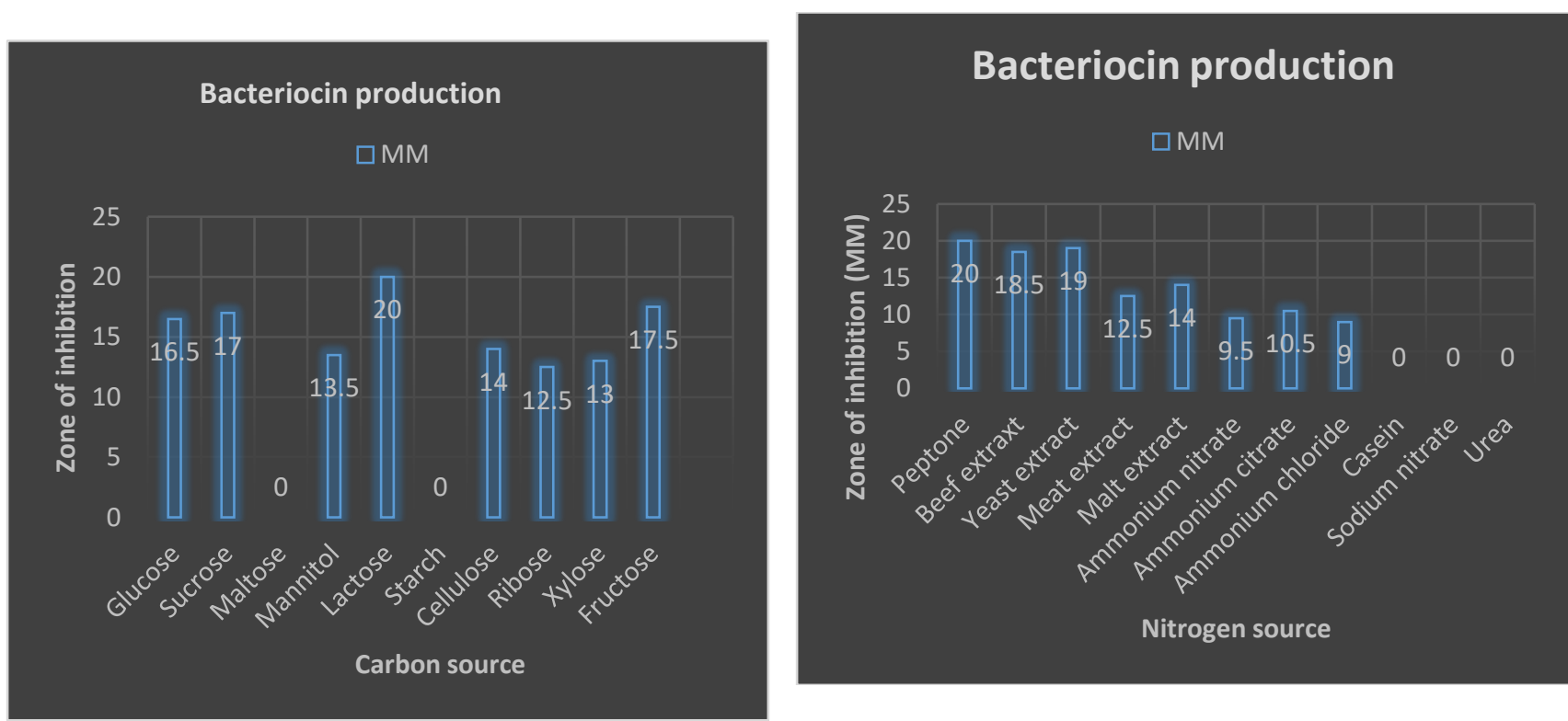

Figure 6: Effect of carbon and nitrogen source on production of bacteriocin

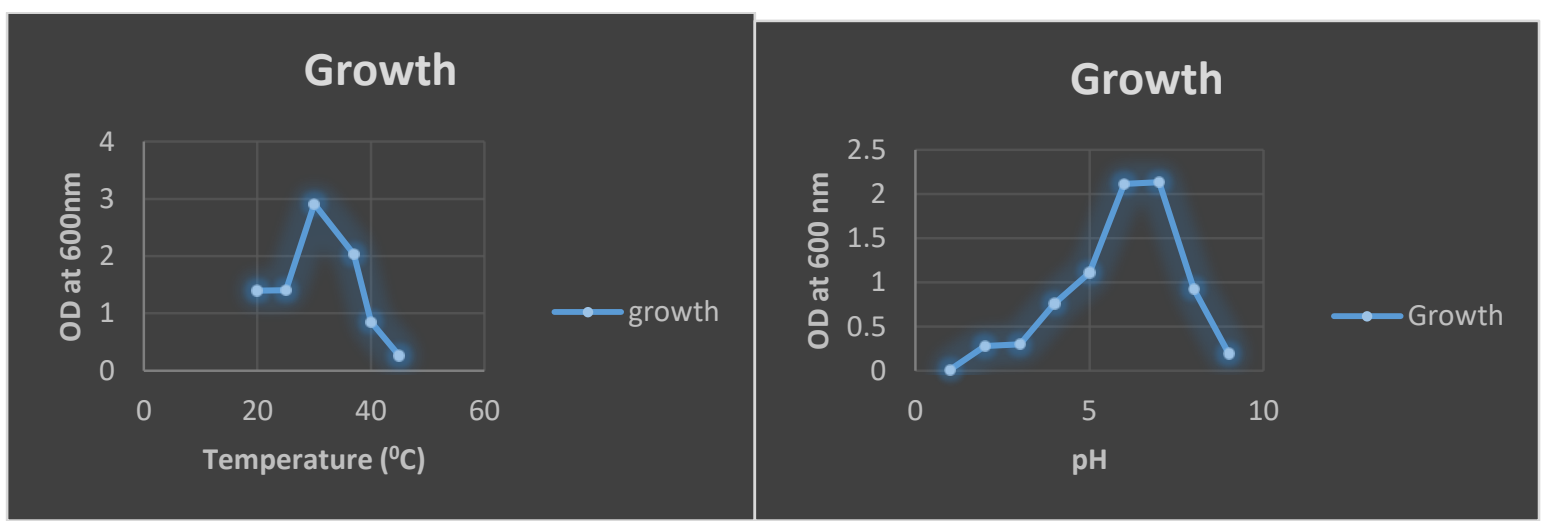




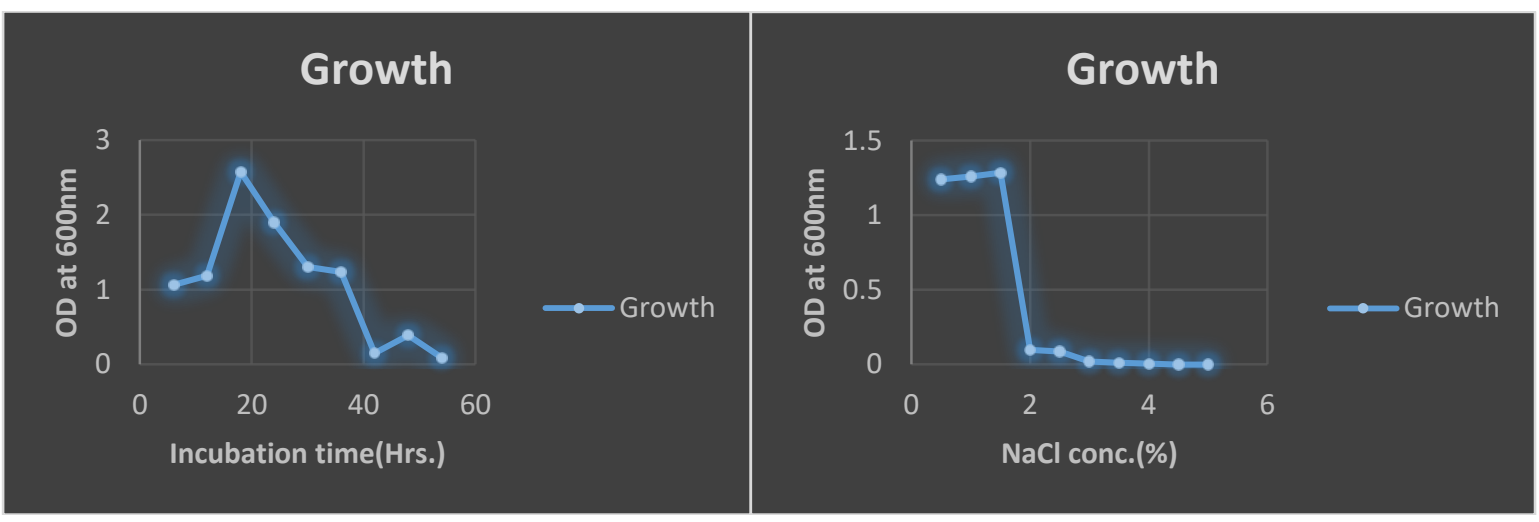

Figure 7: Growth kinetics of lactobacillus rhamnosus L43 At different condition

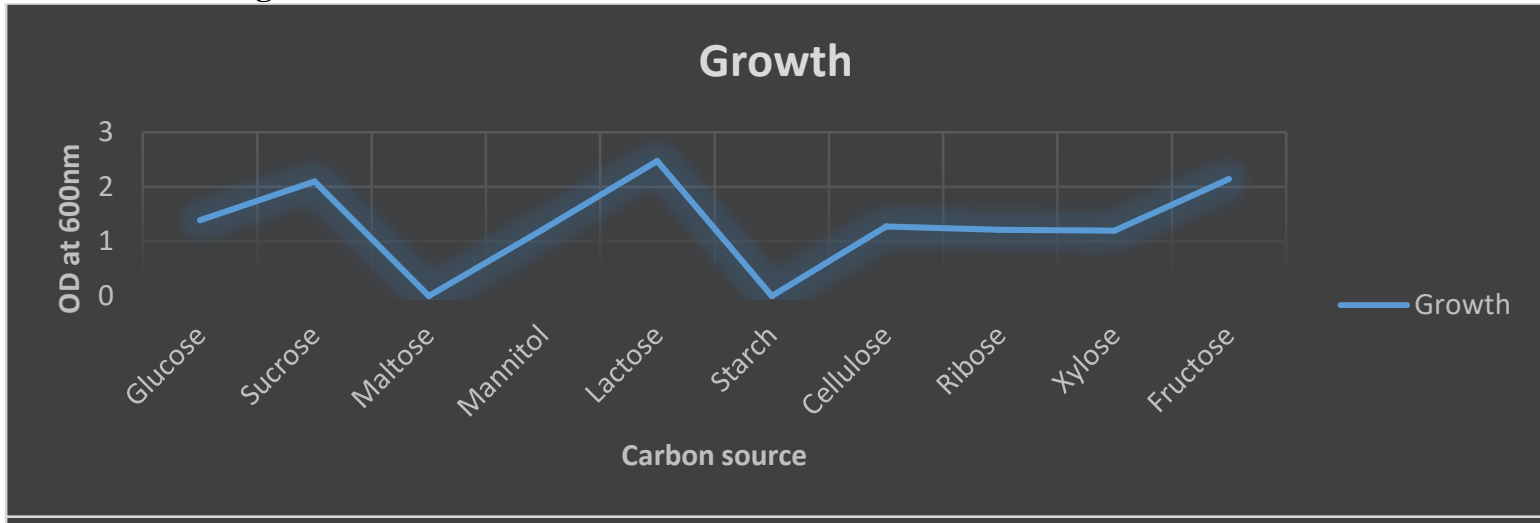

\section{Growth}

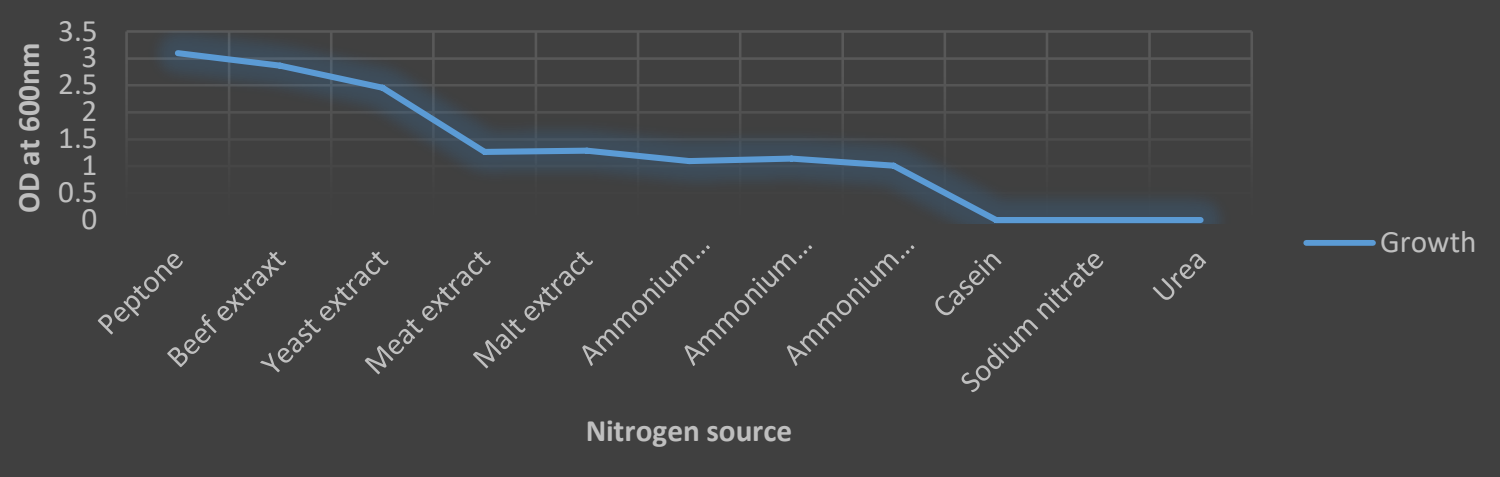

Figure 8: Growth kinetics of lactobacillus rhamnosus L43 at different carbon and nitrogen sources

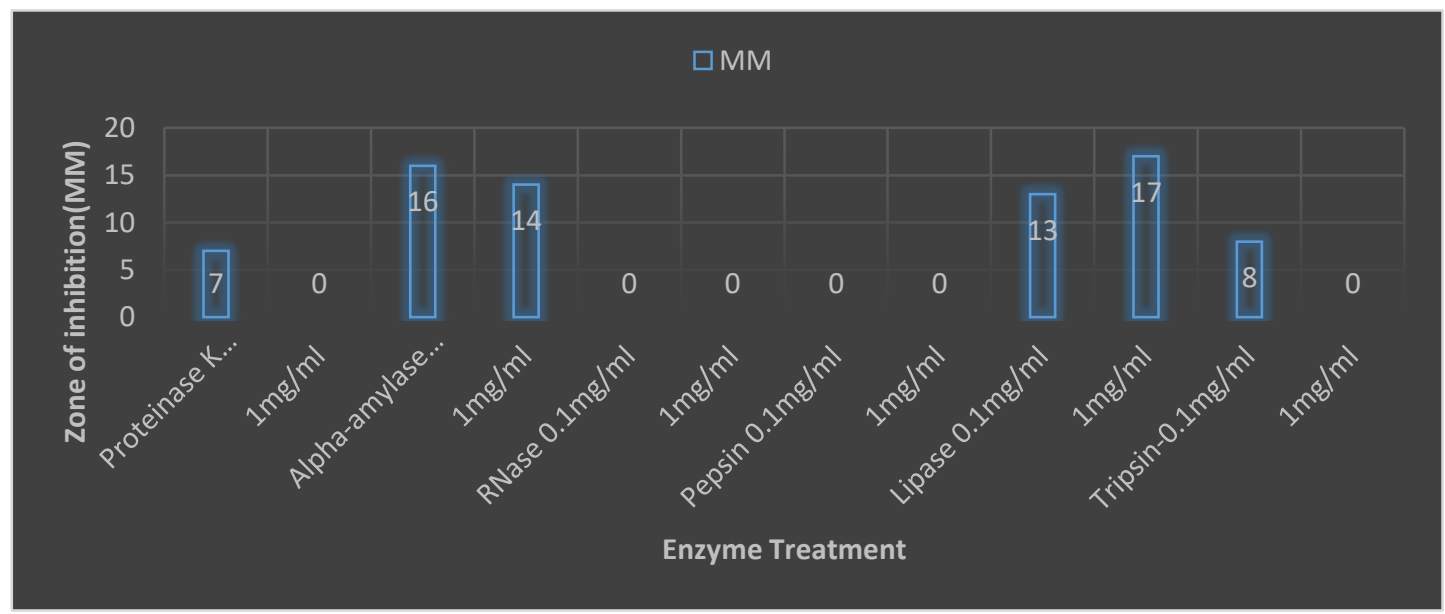




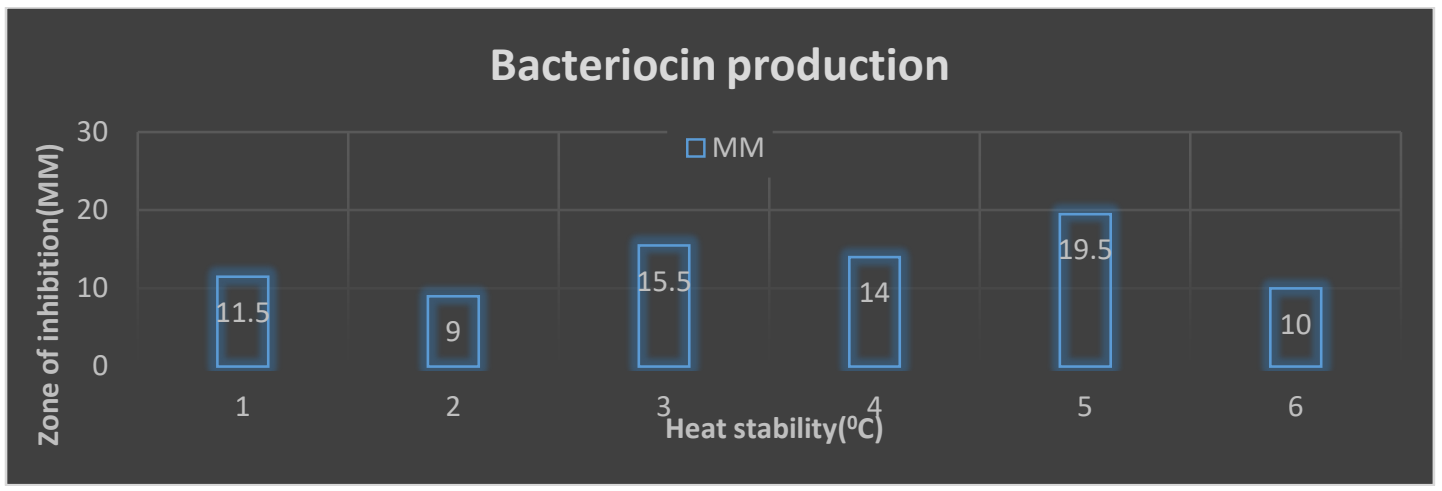

Figure 9: Characterization of crude bacteriocin- Heat stability, Enzyme treatment.

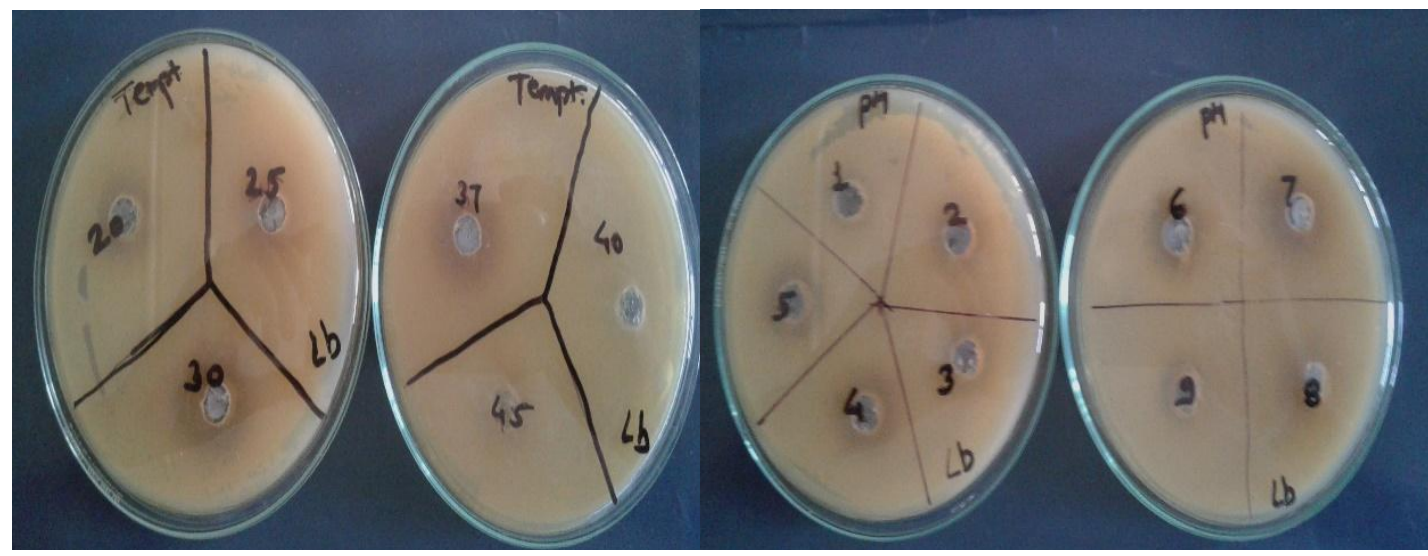

Figure 10: Effect of temperature and $\mathrm{pH}$ for production of bacteriocin

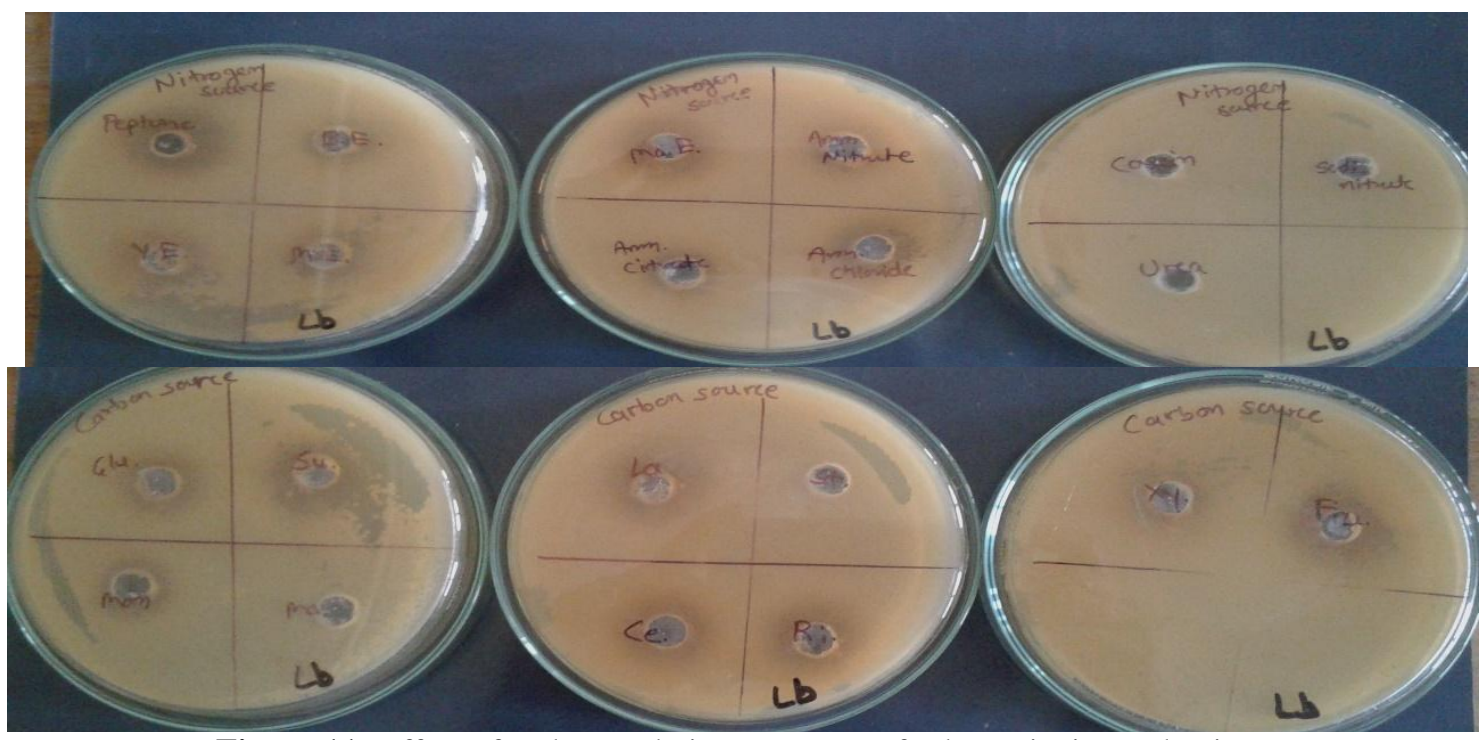

Figure 11: Effect of carbon and nitrogen source for bacteriocin production

\section{Conclusion:}

Study reported on the biodiversity of Lactic acid bacteria (LAB) in the water and sediments in the coastal areas of India. The LAB isolates inhibited pathogenic and spoilage causing Gram positive and Gram negative strains and hence possessed a broad spectrum of activity. These results indicated the potent strain produce bacteriocin. Maximum bacteriocin production was observed at $30^{\circ} \mathrm{C}, 18 \mathrm{hrs}$. incubation, $\mathrm{pH} 7.0,2 \%$ $\mathrm{NaCl}$ solution. In addition of enzymes, alpha amylase, RNAse, lipase, were slightly positive effect bacteriocin production. Proteinase-k, pepsin, trypsin were strongly inhibited bacteriocin production. The activity of bacteriocin remained constant after heating at $100^{\circ} \mathrm{C}$ for $20 \mathrm{~min}$. The isolation, characterization and optimization of the bacteriocin producing strain from the extreme environment like marine would provide lead to approaches like bio preservation. 


\section{Conflict of interest statement}

We declare that we have no conflict of interest.

\section{Acknowledgment}

The authors are extending their thanks to Director, Government Institute of Science, Aurangabad, and Maharashtra. We express our gratitude to DST, Delhi for accepting project (Ref No: SR/WOS-A/LS-210/2013).

\section{References}

[1] Parada J , Caron C, Medeiros A and Soccol C. Bacteriocins from lactic acid bacteria: purification, proprieties and use as biopreservatives. Braz. Archives Biol. Technol.2007 50 (3):521-542.

[2] Lee,H. and Kim H.Y.(2011),. Lantibiotics, class I bacteriocins from the genus Bacillus. Journal of Microbiology and Biotechnology, 2011; 21:229-235.ISSN 1738-8872.

[3] Field D., Cotter P., Till C. and Ross R. P. Bacteriocin biosynthesis, structure and function. 2007; pp.5-14, IJBN 1-904933-23-8, Norfolk, U.K.

[4] Heng, N.C.K., Wescombe, P.A., Burton, J.P., Jack R.W. and Tagg, J.R. The diversity of Bacteriocin in Gm+ve bacteria, 2007; 4592.

[5] Altschul, S. F., Gish, W., Miller, M., Myres, E. W. and Lipman, D.J. Basic local alignment search tool. J. Molecular biology, 1990; 215(3): 403-410.

[6] S.T. Ogunbanwo*, A.I. Sanni, and A. A. Onilude. Characterization of bacteriocin produced by Lactobacillus plantarum F1 and Lactobacillus brevis OG1African Journal of Biotechnology 2003; 2 (8): pp. 219-227.

[7] Ivanova, I., P. Kabadjova, A. Pantev, S. Danova, X. Dousset. Detection, purification and partial characterization of a novel bacteriocin Substance produced by Lactoccous lactis subsp. lactis b14 isolated from Boza-Bulgarian traditional cereal beverage. Biocatalysis, 2000; 41(6): 47-53.

[8] Kanagaraj Nithya1, Duraisamy Senbagam2, Balakrishnan Senthilkumar1*, Narayanapillai Udhayashree1 and Ramasamy Gurusamy. Characterization of bacteriocin producing lactic acid bacteria and its application as a food preservative African Journal of Microbiology Research 2012; 6(6), pp. 1138-1146.

[9] Sarika AR, Lipton AP and Aishwarya MS. Bacteriocin production by a new isolate of Lactobacillus rhamnosus GP1 under different culture conditions. Advance. J. Food Sci. Technol., 2010; 2 (5): 291-297.

[10] Khosro Issazadeh1+, Mohammad rezamajid - Khoshkholgh Pahlaviani2 and Alireza Massiha3. (2012) Isolation of Lactobacillus Species from Sediments of Caspian Sea for Bacteriocin Production. 2nd International Conference on Biomedical Engineering and Technology IPCBEE 2012; 34.

[11] S.D. Todorov and L.M.T. Dicks. Comparison of two methods for purification of plantaricin ST31, a bacteriocin produced by Lactobacillus plantarum ST31. Enz. Microbiol. Technol. 2004; 36:318-326.

[12] Delgado A, López NAL, Brito D, Peres C, Fevereiro P, Garrido- Fernández A (2007). Optimum bacteriocin production by Lactobacillus plantarum $17.2 \mathrm{~b}$ requires absence of $\mathrm{NaCl}$ and apparently follows a mixed metabolite kinetics. J. Biotechnol., 2007; 130:193-201

[13] Rajesh Singh*1, K. Sivasubramani1, S. Jayalakshmi2, S. Satheesh kumar3 and C.Selvi3. Isolation and production of bacteriocin by marine Lactobacillus fermentum SBS001Int.J.Curr.Microbiol.App.Sci 2013;2(4): 67-73.

[14] Harris LJ, Flemming HP, Klaenhammer. TR. Developments in nisin research. Food Res. Int., 1992; 25: 57-66

Bharti Prakash Wadekar. "Optimization and Physico-Chemical Characterization of a Bacteriocin Produced By Marine Lactobacillus Rhamnosus L43." IOSR Journal of Environmental Science, Toxicology and Food Technology (IOSR-JESTFT) 11.7 (2017): 21-28. 